\title{
"To Believe in God and in Own Personal Competencies": The Family Life of Arab Muslim Widowed Women in Israel
}

\author{
Yossi Maman, Janan Falah, Inas Hijazi \\ The Arab College for Education Haifa Israel, Ohalo College, Katzrin, Israel \\ Email: Jananf81@gmail.com,docmaman@gmail.com
}

How to cite this paper: Maman, Y., Falah, J. and Hijazi, I. (2019) "To Believe in God and in Own Personal Competencies": The Family Life of Arab Muslim Widowed Women in Israel. Open Journal of Social Sciences, 7, 37-48.

https://doi.org/10.4236/jss.2019.78003

Received: February 11, 2019

Accepted: August 6, 2019

Published: August 9, 2019

Copyright ( 2019 by author(s) and Scientific Research Publishing Inc. This work is licensed under the Creative Commons Attribution International License (CC BY 4.0).

http://creativecommons.org/licenses/by/4.0/

\begin{abstract}
This study is of five Muslim widowed women from the Arabic city of "Tabula" (a fictitious place for ethical reasons) from the north of Israel, out of a desire that they would expose their personal experiences (Spradley, 1979) [1]. It deals with women's personal status, the widows' difficulties, and the conflicts between the Arab Muslim traditional society and modernity. The Arab society is a traditional, collective, patriarchal and religious society. The women's status is considered inferior to that of the men's and their main role is conceived as raising children and taking care of the house. Following are the stories of Muslim women who became civilian widows by the ages 30 to 40 . The study examines the way widows coped with their situation in a time in which the society underwent great changes, moving from a traditional society to a more modern one. By dealing with this situations: 1) The personal changes; 2) The main difficulty of being lonely; 3) The return to religion; 4) Coping with the loss of the husband; 5) The women' expectations out of the Arab society.
\end{abstract}

\section{Keywords}

Widows, Women Status, Muslim, Society, Arab, Israel

\section{Theoretical Background}

\subsection{Widowhood}

Loss, unfortunately, is the lot of all individuals, regardless of state, gender, age or ethnic group. The death of a spouse is an overwhelming event in an individual's life, which accompanies him many years afterwards. Carnelley, Wortman, Bolger and Burke (2006) [2] found that the mourning and bereavement pursuant the 
death of a spouse extends over a long period of time. Even after many years, memories and talks about the deceased spouse, which cause sadness, are common. Sometimes, the individual experience distresses in certain dates such as the deceased remembrance-day.

Psychodynamic scholars see the loss as a process in which the individual gives up his attachment to the deceased spouse. Yet, the relation between the libido instinct remains after the spouse's death and the process of detachment (the libido energy and the emotions neutralization, without forgetting the deceased) is accelerated as time passes by. This process is known as "the loss" (Schut \& Stroebe, 2005) [3].

A current interesting approach is the use of short-term therapy for dealing with loss. The pioneer of this approach was James Mann (1973) [4] who emphasized the interpersonal facet, in contrast to the classic psychoanalytical approach which defines the difficulties in Oedipal terms.

\subsection{Widows in the Arab/Druze Traditional Society}

The traditional Arab culture sees marriage as a component in the psychological and social development of the individual (Abu-Baker, 2010) [5]. That is, an individual gets married in order to reach the maturity and responsibility stage. Such cultural perceptions intensify the view according to which events such as divorce, separation or becoming a widow, create a crisis, which, besides causing mental stress, present women as needy in many realms (Cohen \& Savaya, 2005) [6], 2006; Abu Baker, 2010) [4].

According to Abu Baker (2010), [4] several variables are related to the widows' odds to remarry in a traditional society. A widow's chances to remarry are higher as long as she is young, her family is well off; and she has no children. Her ability to run her life independently is dependent upon her education level and her economic independence. Second marriage shall mostly take place with a spouse who is considered "inferior" in terms of age or status, and in case she refuses to remarry, she shall live under her relatives' supervision.

Abu-Baker (2002) [7] claims that the social status both of divorcees and of widows is the lowest in the Arab family hierarchy. Such women are expected to avoid sexual relationships and social "scandals", and for that end they are supervised by society. Yet, unlike the divorcees, who are blamed for their situation, the widows get some sympathy from society. According to Abu-Baker (2010) [5] a widow is supervised both by her own family and by her deceased husband's family. Such supervision causes her difficulties, and adds to her sense of loss (Abu-Baker, 2010) [5]. These claims are congruent with previous studies (for example, Al-Krenawi, 1996) [8] according to which the Druze society expects the widow to be weak, in contrast to the widower, and to experience a long term dysfunction and psychosomatic distress, which symbolize the intensity of her loss and the couple relationship which has been lost. Women that do not act in accordance with this expectation, encounter explicit or implicit criticism and condemnation. Israeli-Palestinian widows experience a significant decrease in 
their personal wellness, loose their independence and sometimes their joy of life.

Other studies which focused on analyzing the rights and the economic, social and legal status of mothers in single-parent families in the Israeli society, showed that due to the weakening of the ideology which supported the welfare state and the intensification of the non-liberal view which undermined the foundations of the welfare state, the policy related to mothers in single-parent families was shaped and the former allowances policy, was minimized; Toledano a \& Eliav, 2010) [9]). In countries which do not bestow a generous social support and an active policy of helping working women, a large part of the mothers in single-parent families deteriorate to poverty (Svirsky, Konor-Atias \& Abu-Chala, 2008) [10]. Accordingly, the consequences of cutting the food allowances and the assurance of income in the framework of the 2003 state budget can be seen. In the framework of that cutting, the increased rate of the assurance of income was abolished for most of the entitled individuals, including the single-parent families (Faraj Falah 2009) [11].

Israeli-Palestinian mothers from single-parent families encounter additional barriers which are derived from their civilian status, including: limited job opportunities, limited public transportation services, a lack of proper education frameworks, lower level of public services (Yonai \& Kraus, 2009) [12], few social contacts and discrimination. The later, according to Herzog (2004) [13] constitute a main factor, which makes it hard for Israeli-Palestinian women to find their place in the labor market. The national-based discrimination on the one hand and the gender-based exclusion on the other hand, make it hard for Israeli-Palestinian mothers from single-parent families to find a job and thwart the chances of such families, in which the salary is limited to one provider, to strive to economic independence. (Faraj Falah 2016) [14].

\section{Research Methodology}

This study is done by the qualitative method of "case study", which is based on up-close, in-depth, and detailed examination of a phenomenon (Behrendt, 2017) [15]; Stake, 2005) [16]. Thus, by the use of the "holistic method", (Abuhab, 2013) [17] the researchers aims to reveal, to learn and understand the inner world of "subjects" from their point of view (Toval-Mashih, 2013) [18], Denzin \& Lincoln, 2000) [19]. According to this approach, certain behavior is originated by various factors: definition, beliefs, values and ideologies of the "subjects" (Pelto \& Pelto, 1978) [20]. The main field work is based on in-depth ethnographic interviews, which are built up as the primary source of information, allowing the interviewee to express her story freely and at the same time to stay focused on the research questions and targets (Kapel-Green \& Mirsky, 2013 [21]; Shkedy 2011 [22]; Fontana \& Frey 2005 [23]; Faraj-Falah \& Maman, 2017 [24]; Maman \& Faraj-Falah \& Napso, 2018 [25]).

The interviews were conducted with five Muslim widowed women from the Arabic city of "Tabula" (a fictitious place for ethical reasons) from the north of Israel, out of a desire that they would expose their personal experiences (Sprad- 
ley, 1979) [1]. The time and place of the interviews was carried out by phone, the interview itself was conducted at the widows' home, for about 50 minutes (each interview), and their words were documented in writing during the interview.

As mentioned below (Table 1), the interviewees received "structured" questions, prepared in advance by the following order innovative quality, (Hugh-Jones, 2010 [26]; Wilson, 2016 [27]; Faraj Falah-Maman, Faraj-Falah \& Maman 2017 [24]; Maman \& Faraj-Falah \& Napso, 2018) [25].

\section{The Structured interview questions:}

1) Tell me about your family's background and how your husband died.

2) Describe in general the life in your family with you husband.

3) Describe the division of roles in your family in the past.

4) Describe your difficulties as a widow

5) How do you manage these difficulties?

6) Have you had a personal change since your husband died?

7) Is it possible to overcome the loss of a husband?

8) What kind of changes should the Arab society undergo in order to enable adaptation of widows?

9) What is your best advice to new widowed women?

The data of the built-in interview has been carefully read and is analyzed in accordance with the categories which have been prepared in advance in the phase of the construction of the interview for each question separately (Gevaton, 2001 [28]; Miles \& Hubermaan, 1994) [29]. The analysis of each question is done by the Emic approach, that is to say, the construction of topics and sub-topics are developed out of the interviewees' answers (Glaser \& Strauss [30], 1967: Miles \& Hubermaan, 1994 [29]; Bawa, 2017) [31]. Tzabar (1995) [32] argues that this process lacks of shortcuts, in which, the researcher is looking within the obvious content for important and repeated motives. The researcher phrase those categories, select the statements and place the pieces together (Shkedi 2010 [33]; Charmaz, 2005 [34]; Perakyla, 2005 [35]; Shanthi, 2017) [36]. Shkedi (2003) [37] adds that in the course of the analysis of data we associate words and phrases into categories that become meaningful, mainly in relation to other categories.

\section{The Findings}

The Arab city "Tabula” (A fictitious city for ethical reasons)

Table 1. The interviewees' cross section.

\begin{tabular}{ccccccc}
\hline No. & $\begin{array}{c}\text { Fake } \\
\text { name }\end{array}$ & Age & $\begin{array}{c}\text { Years of } \\
\text { widowhood }\end{array}$ & Education & $\begin{array}{c}\text { No. of } \\
\text { Children }\end{array}$ & Current occupation \\
\hline 1 & Gamila & 40 & 6 & High school & 3 & Not working \\
2 & Assma & 42 & 8 & B.A. & 4. & Kindergarten Teacher \\
3 & Samia & 38 & 4 & High school & 3 & Assistant kindergarten Teacher \\
4. & Manal & 32 & 3 & High school & 2 & Not working \\
5 & Khulud & 37 & 8 & High school & 2 & Not working \\
\hline
\end{tabular}


"Tabula" was declared a city in 1996, it is stated in the Northern District of Israel, on jurisdiction of approximately 30,000 hectares. According to the data of the Central Bureau of Statistics in 2016, the city has 32,804 residents, with an annual growth rate of $1.3 \%$. There are 11 elementary schools, 4 junior high schools and 3 high schools. It also has vocational training schools, a special education school, and a music school for Palestinian folklore, along with many community centers for youth and an extension of the Open University, active theatre and an art gallery. The percentage of eligible for a matriculation certificate is $64 \%$, and the average monthly salaryof an employee stands on NIS 5186 (the national average is NIS 8465) (by Wikipedia).

\subsection{Interview Analysis}

\subsubsection{The Family Background}

The women's socioeconomic background is varied, some come from poor families. Khulud describes, "I was the eldest among eight children, I barely finished $7^{\text {th }}$ grade when I had to leave school to take care of my mother and brothers. At the age of 16 I met my husband and was married by the age of 18. My husband did not have steady work so we had to rent a house. One day he got a stroke and died". Gamila also had to work when she was a student, as she describes "I come from a large family with 9 brothers and sisters. I couldn't continue to higher education, and therefore, I begun working in a factory-where I met my husband and we got married. At the age of 19, I already had three children. One day my husband was diagnosed with cancer. He suffered for three years before dying, finally he died at the age is of 34. Manal also describes a large family "I grew up in a very loving home; we were two girls and five boys. I was a very good student in school but my parents couldn't afford sending me to the university". I met my husband at a very young age and married him at the age of 20. We have two children. Four years after our wedding, my husband had a complicated surgery; he became paralyzed for four years, until he died. Unlike the other women, Assma comes from an economically based family "I was raised to educated parents; my mother was a teacher and my father a lawyer. We were five persons at home, I was the youngest. I graduated high school and went to College, and meanwhile, I met my late husband. I graduated college and we got married, we have three children. It was all falling apart with my husband's death in a car accident". Samia also describes well established family "I grew up in a loving home, an only child between 4 boys, I was spoiled and got everything I ever wanted. When I graduated high school, I was already in love with my husband. Two years after, I got engaged and married. We were a happy couple and brought to the world three children. One day, I got a phone call from his workplace, I was told that there was an accident and he is in hospital, when I got to the hospital, he was already dead".

\subsubsection{Their Life with Their Husband and Family}

According to the interviewees, until the death of the husband, life was good. For 
example, Gamila describes that "I had a normal life with my husband, we had mutual respect and he provided us well, he worked day and night to provide us". Samia adds, "I wanted to work but he wouldn't let me, he wanted me to take care of the children. He was a good man". Khulud is the only interviewee that refers the period differently, as problematic, "I loved my husband very much, yet, we were poor, thus, poverty and insecurity prevent love, and as a result, we had many problems. We always were worry how we would withstand the economic strains on monthly basis-how we would succeed paying the rent. I think he had a heart attack due to the enormous stress and problems".

\subsubsection{The Division of Roles in the Family. (Including the Aspect of Childcare)}

Most interviewees describe clear gender division of roles, that is to say, the wife is at home and the husband is working. As Gamila specifies, "The division of role was routine, I worked at home and took care of the children, cleaning, cooking and taking care of the house. My husband was working, he was the provider, and when he came back home, everything was perfect, including the children. We ate together and rested, he didn't lay a finger at home". Manal also describes "As was customary, I was at home with the children all time, he worked and brought money. When he became ill, I treated him as well". Khulud inserts, "I was at home all the time, cleaning, cooking and taking care of the children. He always worked, true, he didn't have a steady job but he got up working every day, when he was not working, he got out to find a job until he found one". Assma was the only interviewee that worked, "I was a kindergarten teacher, and my husband always helped me at home due to the fact that I always worked, we equally shared responsibilities in taking care of the children, also regarding the domestic roles-the cooking, cleaning and babysitting of the children. This is definitely not typical to the Arab society man".

\subsubsection{Life as a Widow}

All the women defined the difficulty in coping financially, yet they also emphasize the social difficulty, mainly in the inner circle within the family. Gamila shares her pain with us, "There are quite few problems, first of all, I have to deal with my teenage children alone, each one of them and his specific requirements and craziness. I find myself in constant struggle, what is right and what is wrong to do. The poverty that I have to I deal with, for the allowance is not enough, I want to save some for the future of children. The hardest thing is being alone, with no one to share the burden". Assma also emphasizes life of solitude "The hardest thing is that my husband is not with me and I'm all alone. All the beautiful things we had planned together. Loneliness is so hard, taking care of the children alone, appealing to people to get aid". Thus, solitude is emphasized in broader context of the community, as Samia describes, "Loneliness, the splitting of time between home and work, the question is how I would survive living alone, with all the gossip around me", as is emphasized by Assma as well "Society does not feel sorry for women like us", and Manal adds, "Being a widow 
means suffering people's talk and rudeness constantly, to live in a place that I wouldn't stay if not the circumstances". Khulud portrays a particularly difficult situation "I find it hard to return back to my parents' home with two kids. Poverty and deprivation badly hurt us, in addition, my relationship with my husband's parents broke up, and the rumors people spread, everything is difficult, especially because I was left alone".

\subsubsection{Coping with the Difficulties}

All interviewees said that there is no substitute for their husband and they all get financial aid by welfare officials or parents, as Assma illustrates, "Facing these difficulties without my husband, on my own. I have to be supported by my parents, they help me a lot". It appears that faith is the main factor for their strength. Gammila describes that "Thanks to God that allows me to live with dignity, also to my parents who are really supportive and to Welfare authorities, I try to support my children as much as possible". Samia also shares, "I am a believer, faith facilitates difficulties, and the support of my parents and loved ones, along with being a strong woman, helps me coping every day difficulties". Manal emphasizes that "I mainly trust God and then myself. It's not easy to be "under a magnifying glass", especially because I live above my father-in-law and under simple conditions. School is also supportive as well as my parents". Khulud also highlights faith as a primary theme, "I'm a religious woman, supported by my faith in God, an element which elevates coping. I also stay with my parents who are very supportive. Economically, the allowance is quite sufficient for me and for my children".

\subsubsection{The Personal Alteration since Widowhood}

It is clear by the interviewees' answers that the death of the husbands strengthen and empower them, compelling them to become more independent than when they had lived with their husbands. Gamila states that, "I found out that I'm stronger. At first I thought my life is over and I won't be able to survive. Now I realize that I'm strong and able to cope". Assma emphasizes that "When my husband died, I asked myself a lot of questions, especially how would I live alone. Now I know that each obstacle strengthen me, not weakens. I became more independent than I ever thought I would be" Samia also emphasizes that "I've been through a lot of changes, especially in relation towards my capabilities, and now I know to run my house by myself, I'm independent, responsible and strong for my kids". This process Manal also has experienced-"Since my husband became sick, I became stronger. His death gave me a chance to cope, there is no doubt that I have become more independent". Khulud confesses that, "I felt I had more power than I thought."

\subsubsection{Overcoming the Loss of the Husband}

All interviewees emphasize that the loss of the husband was extremely difficult, a situation that is very hard to overcome, for example, Gamilla describes that "You cannot overcome it, he will always be in my heart and mind". Assma says that "I 
never overcome his death, nor get over it in the future. He was a kind of man that every woman would want", Samia notes, "I did not get over him and won't get over in the future, he will always have a special place in my heart". Manal adds, "It is hard to overcome, although he became sick for several years before he passed away, and yet, I didn't want him to leave, he is too good to be forgotten". According to Khulud, "Although our difficulties through years, I can't overcome his death, especially after all the problems that have emerged after his death. I pray a lot that God would wake me up from this nightmare, yet, I'till fid myself living it".

\subsubsection{The Changes That the Arab Society Should Embrace in Order to Allow Widows' Adaptation}

All the interviewees emphasize their need in respecting their privacy in order to cope with their state. Gamila indicates that "Society needs to undergo a change in order to begin understanding the importance of privacy for widowed women", Assma claims that "Society should treat a widowed woman equally to all other women, and the same it treats widowed men, to provide privacy rather examine her under a magnifying glass". Manal specifies, "The Arab society should understand that widowed women are entitled, as much as widowed men, to remarry. Society should undergo a process in order to understand the importance of privacy for widowed women", Khulud also emphasizes the right to remarry, "Society must undergo a process in order to understand the importance of privacy for widowed women, as widowed men have, and the right to remarry".

\subsubsection{Advices for Women Who Are Became Widowed}

The interviewees indicate that proper adjustment is made by "faith". Gamila claims that "First you must understand that the world is not ended, it probably harder and requires strength and faith in God. You must have faith and believe indestiny, and that God would help you". Assma also mentions "the need to understand that crying is not the right way, you are allowed to cry and grieve, but on the other hand, you are required to have a strong will power for the sake of your children. You need to believe in God and pray. A pray greatly relieves and enables powers that you didn't believe you have". So does Samia, "Faith, a pray, taking the right decisions and internal power that is what required at times of distress, to assist you overcoming the tragedy". Manal emphasizes the importance of the future "to look to the future, to plan for years ahead and to understand that there is no other choice except for the gathering strength and faith to adapt the new state". Khulud accepts her faith "Death is God's will, Ifa woman believes in God, in own abilities, and she is determined, she would be able to adapt to the new life".

\section{Summary}

These are the main conclusions from the study:

1) The age of marriage - the interviewing women in this study reported that they got married in their 20s, at young age. Most of them did not acquired high- 
er education or profession, some even left school in the middle. Thus, the socialization of playing the role of motherhood and the establishment of a family (as part of engagement-wedding-having children) was premature, preventing the women from working, and as a result, from being exposed to experience and challenges outside their narrow circle of the family unit.

2) The initial standpoint towards functioning within the family unit-The basic initial concept of the women is that there is a clear division of labor/gender in the house, the husband is "the provider" and the wife is responsible to the domestic roles within the house and taking care the children-"my role" as they describe. We assume that this perception was conveyed since childhood, within the family they had grown in, in the course of being exposed to their mother's roles and functioning. We accept this attitude as part of preserving the "cultural codes" which are common in the traditional Arab society.

3) The main difficulty of being lonely-The death of the husband has created great financial difficulty, yet, the widows continue to function both by the aid of Welfare and the support of their parents. It appears that the main difficulty is social, mainly their sense of loneliness ("there is no one to share the burden with"), even though the Arab widow has few social circles of-children, parents and the family of the deceased husband.

4) The personal changes-The interviewees highlight that the difficulty (the death of the husband) only increased their recognition in their personal capabilities ("I found out that I'm strong and capable"), and made them, in the course of time, independent, more responsible and with greater ability to cope with the tasks at home and within the family all by themselves ("I know now to be independent").

5) Coping with the loss of the husband-All the widows confess that despite the time that had passed since their husbands' death, and despite facing the complex reality of raising the children and running the house all by themselves, they cannot overcome the loss of the husband ("did not overcome, won't overcome").

6) The return to religion-This is an interesting point, all women specify that faith in God has assisted them to cope and adjust to the situation, and at the same time, had increased their inner beliefs in their own personal capacity ("the woman believes in God and in her own abilities").

7) The women' expectations out of the Arab society-all interviewees expect the Arab society to undergo changes in order they would feel "equal" to widowed men, especially in the matter of remarrying ("she has the right to marry as well"). They all mention their need in privacy, to less control or criticism by their society ("not to be under a magnifying glass").

\section{Conflicts of Interest}

The authors declare no conflicts of interest regarding the publication of this paper. 


\section{References}

[1] Spradley, J. (1979) The Ethnographic Interview. Rinehart, New York.

[2] Carnelley, K.B., Wortman, C.B., Bolger, N. and Burke, C.T. (2006) The Time Course of Grief Reactions to Spousal Loss Evidence from a National Probability Sample. Journal of Personality and Social Psychology, 91, 476-492. https://doi.org/10.1037/0022-3514.91.3.476

[3] Schut, H. and Stroebe, S. (2005) Interventions to Enhance Adaptation to Bereavement. Journal of Palliative Medicine, 8, S140-S147. https://doi.org/10.1089/jpm.2005.8.s-140

[4] Mann, J. (1973) Time Limited Psychotherapy. Harvard University, London.

[5] Abu-Baker, K. (2010) Between Independence \& Dominance: The Case of the Arab Widow. In: Abu-Rabia-Quider, C. and Winner-Levi, N., Eds., Palestinian Women in Israel: Identity Power-Relations \& Coping, Van Institute Lir \& Hakibutz Hameuhad, Jerusalem, 27-48.

[6] Cohen, O. and Savay, R. (2005) Lifestyle Differences in Traditionalism and Modernity and Reasons for Divorce among Muslim Palestinian Citizens of Israel. Journal of Comparative Family Studies, 34, 283-302.

[7] Abu-Baker, K. (2002) "Career Women" or "Working Women"? Change versus Stability for Young Palestinian Women in Israel. The Journal of Israeli History, 21, 85-109. https://doi.org/10.1080/13531040212331295872

[8] Al-Krenawi, A. (1996) Group Work with Bedouin Widows of the Negev in Medical Clinic. Affilia, 11, 303-318. https://doi.org/10.1177/088610999601100303

[9] Toledano, E. and Eliav, T. (2010) Single Parent Families 1992-2010. National Insurance Institute of Israel the Planning Department, Jerusalem. http://www.btl.gov.il/Publications/survey/Documents/seker_232.pdf

[10] Svirsky, S., Konor-Atias, A. and Abu-Chalah, H. (2008) Social Current Situation 1998-2008. Adva Center, Tel Aviv. http://www.adva.org/default.asp?pageid=1001anditmid=524\#

[11] Faraj Falah, J. (2009) Widows in Druze Society. Gender, 26, 247-252. https://doi.org/10.1007/s12147-009-9079-7

[12] Yonai, Y. and Krauss, V. (2009) Cultural or a Pattern for Opportunity: Why Do the Majority of Palestinian Women Not Working? In: Azaiza, P. and Abu-Bakar, H., Eds., Arab Women in Israel-Present and Future State, TLV, Jerusalem, 227-258.

[13] Herzog, H. (2004) Both an Arab and a Woman: Gendered, Racialised Experiences of Female Palestinian Citizen of Israel. Social Identities, 10, 53-81. https://doi.org/10.1080/1350463042000190994

[14] Faraj Falah, J. (2016) She Is a Widow: The Story of Six Druze Widows in Israel. Open Journal of Social Sciences, 4, 210-226. https://doi.org/10.4236/jss.2016.49018

[15] Behrendt, M. (2017) Examination of a Successful and Active Science Club: A Case Study. Science Educator, 25, 82-87.

[16] Stake, R.E. (2005) Qualitative Case Studies. In: Denzin, N.K. and Lincoln, Y.S., Eds., The Sage Handbook of Qualitative Research, 3rd Edition, Sage Publications, London, 443-466.

[17] Abuhab, A. and Melzer-Geva, M. (2013) Out to the World and Inner to Myself: Teaching the Qualitative Research in Educational Training. In: Hazan, A. and Notov, L., Eds., Qualitative Research Teaching. Challenges and Principles of Implementation, The Mofet Institute, Tel Aviv, 53-77. 
[18] Toval-Mashih, R. (2013) Challenges, Conflicts and Solutions in Social Sciences Qualitative Research. In: Hazan, A. and Notov, L., Eds., Qualitative Research Teaching. Challenges and Principles of Implementation, Mofet Institute, Ayalon Press, Tel Aviv, 21-51.

[19] Denzin, N.K. and Lincoln, Y.S. (2000) Introduction: The Discipline and Practice of Qualitative Research. In: Denzin, N.K. and Lincoln, Y.S., Eds., Handbook of Qualitative Research, 2nd Edition, Sage Publication, London, 1-28.

[20] Pelto, P. and Pelto, G. (1978) Anthropological Research: The Structure of Inquiry. Cambridge University Press, Cambridge. https://doi.org/10.1017/CBO9780511607776

[21] Kapel-Green, A. and Mirsky, Y. (2013) This Place Is a Nature Reserve That Really Needs to Be Preserved. A Portrait of Mifneh School in the Eyes of Its Members. In: Alpert, B. and Shalsky, S., Eds., The Classroom and School at Closer Perspective-Ethnographic Studies on Education, Mofet Institute, Ayalon Print, Tel Aviv, 108-140.

[22] Shkedy, A. (2011) The Meaning of Words: Methodologies in Qualitative Research in Practice. Tel Aviv University, Jerusalem.

[23] Fontana, A. and Frey, J.H. (2005) The Interview: From Neutral Stance to Political Involvement. In: Denzin, N.K. and Lincoln, Y.S., Eds., The Sage Handbook of Qualitative Research, 3rd Edition, Sage Publication, London, 695-727.

[24] Faraj Falah, J., Maman, Y. and Amasha, W. (2017) Brides across the Border (Syrian Druze Bribes Who Have Married Israeli Druze Men of the Golan Heights after the Israeli Occupation in 1967). Open Journal of Social Sciences, 5, 289-303. https://doi.org/10.4236/jss.2017.55021

[25] Maman, Y., Faraj Falah, J. and Napso, E. (2018) The Social Adjustment of Girls Circassian Students in State Elementary Schools. Open Journal of Social Sciences, 6 , 230-245. https://doi.org/10.4236/jss.2018.61017

[26] Hugh-Jones, S. (2010) The Interview in Qualitative Research. In: Forrester, M.A., Ed., Doing Qualitative Research in Psychology, Sage Publications, London, 77-97. https://doi.org/10.4236/jss.2018.61017

[27] Wilson, A. and Onwuegbuzie, A. (2016) Using Paired Depth Interviews to Collect Qualitative Data. The Qualitative Report, 21, 1549-1573.

[28] Gevaton, D. (2001) A Theory Well Established in the Field: The Significance of the Process of Data Analysis and the Construction of Theory in Qualitative Research. In: Tzabar, N., Ed., Traditions and Trends in Qualitative Research, Dvir, Tel Aviv, 195-228.

[29] Miles, B. and Hubermaan, M. (1994) Qualitative Data Analysis: An Expanded Sourcebook. Sage Publication, Thousand Oaks.

[30] Glaser, B. and Strauss, L. (1967) The Discovery of Grounded Theory: Strategies for Qualitative Research. Aldine, Chicago. https://doi.org/10.1097/00006199-196807000-00014

[31] Bawa, P. (2017) Making Sense of Making Meaning, the Semiotic Way: Emotional Journey of a Novice Learner. The Qualitative Report, 22, 73-104.

[32] Tzabar, N. (1995) The Qualitative Research in Teaching. Modan.

[33] Shkedi, A. (2010) A Theory Supported by Narratives: The Construction of Theory in Qualitative Research. In: Kassen, L. and Kromer-Nevo, M., Eds., Data Analysis in Qualitative Research, the Ben-Gurion University Press, Beersheba, 436-461.

[34] Charmaz, K. (2005) Grounded Theory in the 21st Century: Application for Ad- 
vancing Social Justice Studies. In: Denzin, N.K. and Lincoln, Y.S., Eds., The Sage Handbook of Qualitative Research, 3rd Edition, Sage Publications, London, 507-535.

[35] Perakyla, A. (2005) Analyzing Talk and Test. In: Denzin, N.K. and Lincoln, Y.S., Eds., The Sage Handbook of Qualitative Research, 3rd Edition, Sage Publications, London, 869-886.

[36] Shanthi, T. (2017) Teacher Empowerment: A Focused Ethnographic Study in Brunei Darussalam. The Qualitative Report, 22, 47-72. https://doi.org/10.4324/9780203731802-1

[37] Shkedi, A. (2003) Words That Try to Touch-Qualitative Research, Theory and Application. Tel-Tviv University, Jerusalem. 